\title{
Education Research: Flipped classroom in neurology
}

\author{
Principles, practices, and perspectives
}

Stefano Sandrone, PhD, Jimmy V. Berthaud, MD, MPH, Chad Carlson, MD, Jacquelyne Cios, MD, Neel Dixit, MD, Amtul Farheen, MD, Jessica Kraker, MD, James W.M. Owens, MD, PhD, Gustavo Patino, MD, PhD,

Harini Sarva, MD, Daniel Weber, DO, and Logan D. Schneider, MD

Neurology ${ }^{\circledR}$ 2019;93:e106-e111. doi:10.1212/WNL.0000000000007730

Correspondence Dr. Sandrone sandrone.stefano@ gmail.com

\begin{abstract}
How to most effectively deliver a large amount of information in an engaging environment that encourages critical thinking is a question that has long plagued educators. With ever-increasing demands on both resident and faculty time, from shrinking duty hours to increased patient complexity, combined with the exponential growth of medical knowledge and unequal access to the spectrum of neurologic subspecialties around the country, this question has become especially pertinent to neurology residency training. A team of educators from the American Academy of Neurology's A.B. Baker Section on Neurological Education sought to review the current evidence regarding the implementation of the flipped classroom format. This educational model has only recently been applied to health care education along the training continuum, and a small collection of articles has, so far, used disparate methods of curricular implementation and assessment. While the feedback from learners is generally positive, a number of obstacles to implementation exist, most notably learner time commitments. These are presented with discussion of potential solutions along with suggestions for future studies.
\end{abstract}

From the A.B. Baker Section on Neurological Education (S.S., J.V.B., C.C., J.C., N.D., A.F., J.K., J.W.M.O., G.P., H.S., D.W., L.D.S.), American Academy of Neurology, Minneapolis, MN; Imperial College London (S.S.), UK; University of Michigan (J.V.B.), Ann Arbor; Medical College of Wisconsin (C.C.), Milwaukee; Ohio State University (J.C.), Columbus; Weill Cornell Medicine (N.D., H.S.), New York, NY; Lebanon VA Medical Center (A.F.), PA; Tulane University School of Medicine (J.K.), New Orleans, LA; University of Washington (J.W.M.O.), Seattle; Oakland University William Beaumont School of Medicine (G.P.), Auburn Hills, Ml; St. Louis University (D.W.), MO; and Stanford University (L.D.S.), CA.

Go to Neurology.org/N for full disclosures. Funding information and disclosures deemed relevant by the authors, if any, are provided at the end of the article. 
Historically, education has been dominated by the didactic lecture linked to a passive transfer of information from expert to student through oratory. ${ }^{1}$ Passive, lecture-style learning has indeed been traditional in preclinical undergraduate education and frequently used in graduate medical education didactic series. In recent years, "active learning" is increasingly being applied to higher education. The "flipped classroom" is one of such educational formats, which is characterized by active engagement of students in the learning process. ${ }^{2,3}$

Here, members of the American Academy of Neurology A.B. Baker Section on Neurological Education review and discuss the implementation and the evaluation of the flipped classroom model, underline the open questions, and highlight future opportunities. This article covers undergraduate, graduate medical, and health care higher education, and mentions not only specialties where the flipped classroom approach has been integrated over the last 6 years, but also those where it has been piloted more recently.

\section{Principles of the flipped classroom}

Within the flipped classroom, the work historically done in the classroom is moved outside. The students are given preclass information, whether via reading assignments, interactive presentations, or online prerecorded videos, ${ }^{4}$ and are expected to join the classroom prepared to solidify their understanding under the supervision of a facilitator. The classroom facilitator employs learning activities of various sorts, commonly small group discussions and problem-based learning, with roots in the material experienced outside the class.

The feasibility of the flipped classroom model is a key issue for faculty and students. For educators, flipping the curriculum can be very labor intensive, with potential monetary costs related to preparing and disseminating preclass activities. ${ }^{5,6}$ For students, the unique educational environment of medical school, with limitations on resources and opportunities for hands-on exposure to clinical faculty, renders attractive the idea of offloading the acquisition of facts to preclass preparation, allowing for application of knowledge during class. ${ }^{7}$

\section{Practices in health care, undergraduate, and graduate medical education}

First practiced in primary education and undergraduate education, the use of flipped classrooms in medical education - in both medical school and residency/fellowship-took off around 2012. The focus on heutagogy, which is the investigation of self-directed learning, is relatively recent, and heutagogic practices have slowly percolated into higher education. As a consequence, there is a paucity of high-quality research on the topic. Until 2015, most of the literature on flipped classrooms in health sciences teaching was from the nursing or pharmacy realms. ${ }^{7}$ However, there is an expanding body of research on this topic, with a single article on flipped classrooms in medical education published in 2012 ballooning to 21 topical publications in 2015 . While the majority of students regard the curricular changes to a flipped classroom favorably, ${ }^{7}$ asking residents, who are already working 80 hours a week, to find time prior to lectures to prepare might only work with incentives to encourage participation, such as incorporating dedicated preparation time into the work week, non-call months, or electives. ${ }^{8}$

According to a recent meta-analysis on health science education, the flipped classroom in undergraduate classes has increased students' motivation, class attendance, and satisfaction, while additionally improving higher-order thinking outcomes. ${ }^{9}$ Another recent meta-analysis assessed the effect of flipped classrooms on performance and perceptions across health care domains, including medicine, pharmacy, public health, nursing, dentistry, and chiropractic programs: knowledge acquisition and application improved, and students favored the flipped classroom format. ${ }^{10}$ This accords well with previous metaanalyses in health care education, generally characterized by mixed-to-positive results. ${ }^{11,12}$ However, the flipped classroom format did not garner universal approval from learners, with the majority of students citing time required to complete preclass work as the primary grievance. ${ }^{10-12}$

Despite improvements in engagement, performance improvements are not uniformly demonstrated in all studies. This may be due to variability in content to be learned, faculty experience with the pedagogy or enthusiasm for the educational format, and consistency of educational program delivery. ${ }^{10-13}$ Nonetheless, the inclusion of quizzes at the start of the face-to-face class improved the efficacy of flipped classrooms. ${ }^{10}$ This was attributed to the possibility of ensuring engagement with the preparatory material and priming of the acquired knowledge, as prior knowledge is deemed a key factor influencing learning. ${ }^{14}$ The pretest was also identified as an opportunity for the educator to assess students' potential misconceptions. ${ }^{10}$ A brief list of reports on flipped classroom across specialties is summarized in table 1.

\section{Open questions and future perspectives}

There are many open questions regarding the application and refinement of flipped classrooms in neurology, ranging from best practices to cultural changes among students and educators (table 2). The most pressing question is the effectiveness of flipped classrooms in fostering the development of clinical reasoning. An ultimate answer is lacking: thus far, results are mixed regarding the effectiveness in comparison with traditional lectures. ${ }^{7,9,15,16}$ Moreover, due to variability in the preparatory materials, in-class activities, and assessment tools, ${ }^{17,18}$ there are high levels of study heterogeneity, confounding robust meta-analyses. ${ }^{9,15}$ 
Table 1 Reports on flipped classroom across specialties

\begin{tabular}{|c|c|c|}
\hline Specialties & Title & First author and year \\
\hline \multirow[t]{6}{*}{ Anesthesiology } & $\begin{array}{l}\text { Review article: New directions in medical education related to anesthesiology and perioperative } \\
\text { medicine }\end{array}$ & Bould et al. $(2012)^{\mathrm{e} 1}$ \\
\hline & Blended learning in anesthesia education: Current state and future model & Kannan and Kurup (2012) $)^{\mathrm{e} 2}$ \\
\hline & The changing landscape of anesthesia education: Is flipped classroom the answer? & Kurup and Hersey $(2013)^{e 3}$ \\
\hline & Perioperative ultrasound curriculum to anesthesiology residents & Ramsingh et al. (2014) ${ }^{\mathrm{e} 4}$ \\
\hline & $\begin{array}{l}\text { Effectiveness of a blended learning course and flipped classroom in first year anesthesia } \\
\text { training }\end{array}$ & Marchalot et al. $(2017)^{\mathrm{e} 5}$ \\
\hline & Results of a flipped classroom teaching approach in anesthesiology residents & Martinelli et al. (2017) \\
\hline \multirow[t]{6}{*}{$\begin{array}{l}\text { Emergency medicine } \\
\text { and critical care }\end{array}$} & $\begin{array}{l}\text { The flipped classroom: A modality for mixed asynchronous and synchronous learning in a } \\
\text { residency program }\end{array}$ & Young et al. (2014) ${ }^{\mathrm{e} 7}$ \\
\hline & $\begin{array}{l}\text { Acceptability of the flipped classroom approach for in-house teaching in emergency } \\
\text { medicine }\end{array}$ & Tan et al. (2015) \\
\hline & $\begin{array}{l}\text { The flipped classroom in emergency medicine using online videos with interpolated } \\
\text { questions }\end{array}$ & Rose et al. $(2016)^{\mathrm{eg}}$ \\
\hline & The "flipped classroom" model for teaching in the intensive care unit & Tainter et al. (2017) ${ }^{\mathrm{e} 10}$ \\
\hline & $\begin{array}{l}\text { Bringing the flipped classroom to day 1: A novel didactic curriculum for emergency medicine } \\
\text { intern orientation }\end{array}$ & Barrie et al. $(2018)^{\mathrm{e} 11}$ \\
\hline & Replacing lectures with small groups: The impact of flipping the residency conference day & King et al. $(2018)^{\mathrm{e} 12}$ \\
\hline \multirow[t]{3}{*}{ Nuclear medicine } & Value of case-based learning in a nuclear medicine clerkship & Lee et al. $(2013)^{\mathrm{e} 13}$ \\
\hline & Implementation of a flipped classroom for nuclear medicine physician CME & Komarraju et al. $(2018)^{\mathrm{e} 14}$ \\
\hline & A review of innovative teaching methods & Sivarajah et al. (2018) $)^{\mathrm{e} 15}$ \\
\hline Neuro-otology & Randomized controlled study of a remote flipped classroom neuro-otology curriculum & Carrick et al. (2017) ${ }^{\mathrm{e} 16}$ \\
\hline \multirow[t]{2}{*}{ Internal medicine } & Implementing a flipped classroom cardiology curriculum for internal medicine residents & Allenbaugh et al. $(2018)^{\mathrm{e} 17}$ \\
\hline & $\begin{array}{l}\text { Flipped classrooms in graduate medical education: A national survey of residency program } \\
\text { directors }\end{array}$ & Wittich et al. $(2018)^{\mathrm{e} 18}$ \\
\hline Neurosurgery & Implementation of a "flipped classroom" for neurosurgery resident education & Girgis et al. $(2018)^{\mathrm{e} 19}$ \\
\hline
\end{tabular}

Data available from SDC (references e1-e19): links.Iww.com/WNL/A922

Despite the growing body of evidence, another constant theme is the lack of a one-size-fits-all solution. While many potential benefits have been extolled, the extramural time required is often cited as a deterrent to widespread acceptance by students. As a result, compliance with preclassroom assignments can vary widely from study to study (from $33 \%$ to $88 \%$ ). ${ }^{17,19}$

Flipping the classroom has been reportedly undesirable with certain types of content (e.g., large quantities of unfamiliar jargon) or in student populations without some degree of foundational knowledge. ${ }^{13}$ While different formats may be optimal for different learners and educational content, to date only one study has sought to isolate the effects of active learning from those of the flipped classroom ${ }^{20}$; thus, there is a need to explore how multiple andragogic strategies can serve the multifaceted needs of medical education. As multiple factors may influence the delivery of the teaching session, including the topic, the class size, and the educational level of learners, no single type of in-class activity would best fit all educational opportunities. Nevertheless, selecting the most appropriate one from among all the possibilities reported in the literature can be a challenge, and many times it is done through a trial-and-error approach, ${ }^{5}$ although this is not always feasible, for ethical and practical reasons, within the neurologic curriculum or the clinical context. More deliberate study of the optimal educational delivery formats, given the demands placed on neurology residents and the broad content areas, is critical for understanding how to integrate the new models of learning into resident curricula. Furthermore, it is paramount to align educational methods with the clinical experience: subspecialty rotations offer a unique opportunity to exploit the possibility of matching daily students' activities on service with the out-of-the-classroom didactic sessions. ${ }^{21}$

Another consideration for implementing new educational models, such as the flipped classroom, is alignment of in-class activities and assessment tools used as primary outcomes. While there is consensus that in-class activities should engage 
Table 2 Challenges and potential resolutions

\begin{tabular}{|c|c|}
\hline Challenges & Potential resolutions \\
\hline \multicolumn{2}{|l|}{ Stakeholder: Residents } \\
\hline Preparation time & $\begin{array}{l}\text { Limit required content complexity and volume per session } \\
\text { Limit number of didactics employing self-directed learning and space them out throughout the } \\
\text { year } \\
\text { Vary integration of new formats according to clinical demands (e.g., inpatient vs outpatient } \\
\text { rotations) }\end{array}$ \\
\hline Need for timely feedback & $\begin{array}{l}\text { Provide postsession assessments/tests } \\
\text { Provide summary/takeaway points from the session }\end{array}$ \\
\hline Inexperience with new educational formats & $\begin{array}{l}\text { Gradually transition curriculum } \\
\text { Employ various, adult-learning-theory based approaches (e.g., journal club competitions, } \\
\text { simulation laboratories) } \\
\text { Assess learner perceptions of curricular efficacy and desirability } \\
\text { Employ formats familiar to modern learners (e.g., phone-based) }\end{array}$ \\
\hline Relevance beyond the classroom & $\begin{array}{l}\text { Use sessions to have the learners collaboratively develop tools that bridge the } \\
\text { knowledge-application gap }\end{array}$ \\
\hline \multicolumn{2}{|l|}{ Stakeholder: Faculty } \\
\hline Lack of experience & $\begin{array}{l}\text { Provide training and mentorship } \\
\text { Provide protected time and legitimize promotion track in support of educators }\end{array}$ \\
\hline Lack of uniformity & $\begin{array}{l}\text { Use prefabricated curricula developed for mass distribution } \\
\text { Utilize resources (e.g., ARS) that can help tailor the experience to the audience, while also providing } \\
\text { direction to the session }\end{array}$ \\
\hline \multicolumn{2}{|l|}{ Stakeholder: Program directors } \\
\hline Lack of local expertise & $\begin{array}{l}\text { Develop national, evidence-based, validated curricula for deployment within any program } \\
\text { Aggregate collection of best practices and ad hoc resources for implementation at any program }\end{array}$ \\
\hline Lack of justification/evidence & $\begin{array}{l}\text { Devise new assessment metrics to accommodate the new educational formats focused on } \\
\text { application/performance } \\
\text { Implement assessment metrics as part of the curriculum } \\
\text { Tie curricular assessments to ACGME-based requirements (e.g., milestones) } \\
\text { Track pre-post implementation data through routinely performed assessments (e.g., RITE, board } \\
\text { examinations) } \\
\text { Participate in multicenter efforts to study application of andragogical approaches to residency } \\
\text { education }\end{array}$ \\
\hline Faculty buy-in & $\begin{array}{l}\text { Advocate for faculty educators to have financial support/protected time and promotional } \\
\text { opportunities } \\
\text { Train faculty through exposure and mentorship } \\
\text { Provide resources and structure for content updating } \\
\text { Provide feedback on educational ability } \\
\text { Allow faculty streamlined opportunity to use sessions as part of evaluations of resident ability }\end{array}$ \\
\hline
\end{tabular}

Abbreviations: ACGME = Accreditation Council for Graduate Medical Education; ARS = audience response system .

the learner's active participation, ${ }^{22}$ there is less agreement on the outcomes, for example, whether it should chiefly be the recollection of facts or improvement in problem-solving abilities. While most circumstances would likely favor the latter, the outcomes used in published studies tend to belong to the former. ${ }^{7,9}$ When designing flipped classroom activities or studies, faculty can consider using the Kirkpatrick scale ${ }^{23}$ to select outcome measures truly evaluating the desired objectives of the educational session. As the goal of the in-class activities is to improve the outcome measure, clearly defining the latter is a prerequisite to developing and selecting highquality learning activities.

As a means of monitoring performance, many educational models have adopted content management systems to collect students' answers, including the audience response systems or the use of virtual learning environments. These systems allow tracking the participation and performance of individuals or teams, and online services like Kahoot (kahoot.com) have made such technology widely available. Tracking participation of students is important, as some learners may feel uncomfortable with their new active role in the learning process. ${ }^{5,18}$ While many of the aforementioned technologies can collect narrative answers from learners, the relatively short sessions of flipped classroom do not allow the necessary time to analyze them, in addition to the fact that they are difficult to display for discussion purposes. Thus, most faculty prefer to ask multiplechoice questions. However, reliance upon these nonrobust yet easily quantifiable measures may mask students' superficial mastery of content. ${ }^{24}$ Advances in technology, such as natural language processing, may enable real-time, robust, qualitative assessment of student performance in modern formats. 
Finally, because facilitation of education in new educational formats leverages different skills, faculty development plays a crucial role in ensuring incorporation of the flipped classroom model into medical curricula. ${ }^{7}$ For example, preclassroom content development also relies upon faculty who may lack familiarity with the medium. Online videos are commonly used in flipped classrooms, but faculty members feel less comfortable with the technology required for its development. ${ }^{17,25}$ For this reason, sharing flipped classroom materials through public repositories would allow others to implement a flipped classroom without having to independently develop educational materials, particularly if there is a lack of local expertise. Furthermore, the use of the same materials across multiple institutions would allow the design of more robust studies to assess the efficacy of flipping the neurology curriculum while controlling for institutional factors.

There is increasing interest in and need for evaluating flipped classroom formats in the delivery of neurology education. Although the quantity of available data to assess the role of flipped classrooms is growing in many specialties, there are few studies on the use of the flipped classroom in neurology education. Nonetheless, the evidence from applications in other health professions and medical specialties suggests this heutagogic format might be a viable method for the delivery of some aspects of neurology education. Flipped classrooms may be more effective in areas in which there is a lack of uniformity of expertise in a certain subspecialty, such as sleep medicine, as it allows learners to acquire foundational knowledge at their own pace and reinforces its application during lectures. In addition, while the ideal formats and evaluation strategies are yet to be delineated, a mix of traditional lectures and modern adult learning-based education might prove to be optimal.

Given the large temporal and financial commitments involved in flipping the neurologic classroom, it is pivotal to gauge their effectiveness before broad application. Generally, but not always, learners enjoy the preparatory materials, self-directed pace, and personalization of the flipped classroom. However, we suggest that any newly implemented curriculum begin with a more precise and standardized definition of the materials as well as metrics to determine potential benefits, including learner satisfaction and engagement, educator satisfaction, and assessment of knowledge and skill acquisition. To better elucidate the effectiveness of the flipped curriculum in neurologic education, future studies should also investigate the efficacy of this model in improving knowledge retention and application in neurology learners over a prolonged period of time.

\section{Study funding}

No targeted funding reported.

\section{Disclosure}

S. Sandrone receives royalties from Oxford University Press. J. Berthaud, C. Carlson, J. Cios, N. Dixit, A. Farheen, and J.
Kraker report no disclosures relevant to the manuscript. $\mathrm{J}$. Owens receives honoraria for CME question writing from Neurology ${ }^{\circledR}$ and Continuum. G. Patino reports no disclosures relevant to the manuscript. H. Sarva has 5\% support from the Michael J Fox Foundation, received clinical trial support from Biogen, Insightec, and Lundbeck Pharmaceuticals, and has received some internal funding from Cornell. L. Schneider and $\mathrm{D}$. Weber report no disclosures relevant to the manuscript. Go to Neurology.org/N for full disclosures.

Appendix Authors

\begin{tabular}{|c|c|c|c|}
\hline Name & Location & Role & Contribution \\
\hline $\begin{array}{l}\text { Stefano } \\
\text { Sandrone, } \\
\text { PhD }\end{array}$ & $\begin{array}{l}\text { Imperial College } \\
\text { London }\end{array}$ & Author & $\begin{array}{l}\text { Major role in designing } \\
\text { and conceptualizing the } \\
\text { paper; drafted, wrote, } \\
\text { and revised different } \\
\text { versions of the } \\
\text { manuscript for } \\
\text { intellectual content }\end{array}$ \\
\hline
\end{tabular}

\begin{tabular}{|c|c|c|c|}
\hline $\begin{array}{l}\text { Jimmy V. } \\
\text { Berthaud, } \\
\text { MD }\end{array}$ & $\begin{array}{l}\text { University of } \\
\text { Virginia }\end{array}$ & Author & $\begin{array}{l}\text { Wrote a section of the } \\
\text { manuscript and revised } \\
\text { a previous version of the } \\
\text { manuscript for } \\
\text { intellectual content }\end{array}$ \\
\hline $\begin{array}{l}\text { Chad } \\
\text { Carlson, } \\
\text { MD }\end{array}$ & $\begin{array}{l}\text { Medical College of } \\
\text { Wisconsin }\end{array}$ & Author & $\begin{array}{l}\text { Wrote a section of the } \\
\text { manuscript and revised } \\
\text { a previous version of the } \\
\text { manuscript for } \\
\text { intellectual content }\end{array}$ \\
\hline $\begin{array}{l}\text { Jacquelyne } \\
\text { Cios, MD }\end{array}$ & $\begin{array}{l}\text { Ohio State } \\
\text { University, } \\
\text { Columbus }\end{array}$ & Author & $\begin{array}{l}\text { Wrote a section of the } \\
\text { manuscript and revised } \\
\text { a previous version of the } \\
\text { manuscript for } \\
\text { intellectual content }\end{array}$ \\
\hline
\end{tabular}

\begin{tabular}{lll}
\hline Neel Dixit, & Weill Cornell & Author \\
MD & Medicine, New York & $\begin{array}{l}\text { Wrote a section of the } \\
\text { manuscript and revised } \\
\end{array}$ \\
& $\begin{array}{l}\text { a previous version of the } \\
\text { manuscript for } \\
\text { intellectual content }\end{array}$ \\
\hline
\end{tabular}

\begin{tabular}{|c|c|c|c|}
\hline $\begin{array}{l}\text { Amtul } \\
\text { Farheen, } \\
\text { MD }\end{array}$ & $\begin{array}{l}\text { Lebanon VA } \\
\text { Medical Center, PA }\end{array}$ & Author & $\begin{array}{l}\text { Wrote a section of the } \\
\text { manuscript and revised } \\
\text { a previous version of the } \\
\text { manuscript for } \\
\text { intellectual content }\end{array}$ \\
\hline $\begin{array}{l}\text { Jessica } \\
\text { Kraker, MD }\end{array}$ & $\begin{array}{l}\text { Tulane University } \\
\text { School of Medicine, } \\
\text { New Orleans, LA }\end{array}$ & Author & $\begin{array}{l}\text { Wrote a section of the } \\
\text { manuscript and revised } \\
\text { a previous version of the } \\
\text { manuscript for } \\
\text { intellectual content }\end{array}$ \\
\hline $\begin{array}{l}\text { James W.M. } \\
\text { Owens, MD }\end{array}$ & $\begin{array}{l}\text { University of } \\
\text { Washington }\end{array}$ & Author & $\begin{array}{l}\text { Wrote a section of the } \\
\text { manuscript and revised } \\
\text { a previous version of the } \\
\text { manuscript for } \\
\text { intellectual content }\end{array}$ \\
\hline $\begin{array}{l}\text { Gustavo } \\
\text { Patino, MD, } \\
\text { PhD }\end{array}$ & $\begin{array}{l}\text { Oakland University } \\
\text { William Beaumont } \\
\text { School of Medicine, } \\
\text { MI }\end{array}$ & Author & $\begin{array}{l}\text { Wrote a section of the } \\
\text { manuscript and revised } \\
\text { a previous version of the } \\
\text { manuscript for } \\
\text { intellectual content }\end{array}$ \\
\hline $\begin{array}{l}\text { Harini } \\
\text { Sarva, MD }\end{array}$ & $\begin{array}{l}\text { Weill Cornell } \\
\text { Medicine, New York, } \\
\text { NY }\end{array}$ & Author & $\begin{array}{l}\text { Wrote a section of the } \\
\text { manuscript and revised } \\
\text { a previous version of the } \\
\text { manuscript for } \\
\text { intellectual content }\end{array}$ \\
\hline
\end{tabular}


Appendix (continued)

\begin{tabular}{|c|c|c|c|}
\hline Name & Location & Role & Contribution \\
\hline $\begin{array}{l}\text { Logan D. } \\
\text { Schneider, } \\
\text { MD }\end{array}$ & $\begin{array}{l}\text { Stanford University, } \\
\text { CA }\end{array}$ & Author & $\begin{array}{l}\text { Major role in designing } \\
\text { and conceptualizing the } \\
\text { paper; drafted, wrote, } \\
\text { and revised different } \\
\text { versions of the } \\
\text { manuscript for } \\
\text { intellectual content }\end{array}$ \\
\hline $\begin{array}{l}\text { Daniel } \\
\text { Weber, Do }\end{array}$ & $\begin{array}{l}\text { St. Louis University, } \\
\text { MO }\end{array}$ & Author & $\begin{array}{l}\text { Wrote a section of the } \\
\text { manuscript and revised } \\
\text { a previous version of the } \\
\text { manuscript for } \\
\text { intellectual content }\end{array}$ \\
\hline
\end{tabular}

\section{References}

1. Schmidt HG, Wagener SL, Smeets G, Keemink LM, van der Molen HT. On the use and misuse of lectures in higher education. Health Prof Educ 2015;1:12-18.

2. Prince M. Does active learning work? A review of the research. J Eng Educ 2004;93: 223-231.

3. McLaughlin JE, Roth MT, Glatt DM, et al. The flipped classroom: a course redesign to foster learning and engagement in a health professions school. Acad Med 2014;89: 236-243.

4. Prober CG, Khan S. Medical education reimagined: a call to action. Acad Med 2013; $88: 1407-1410$

5. Moffett J. Twelve tips for "flipping" the classroom. Med Teach 2015;37:331-336.

6. Spangler J. Costs related to a flipped classroom. Acad Med 2014;89:1429.

7. Chen F, Lui AM, Martinelli SM. A systematic review of the effectiveness of flipped classrooms in medical education. Med Educ 2017;51:585-597.

8. Cooper AZ, Hsieh G, Kiss JE, Huang GC. Flipping out: does the flipped classroom learning model work for GME? J Grad Med Educ 2017;9:392-393.

9. Chen KS, Monrouxe L, Lu YH, et al. Academic outcomes of flipped classroom learning: a meta-analysis. Med Educ 2018;52:910-924.
10. Hew KF, Lo CK. Flipped classroom improves student learning in health professions education: a meta-analysis. BMC Med Educ 2018;18:38.

11. Betihavas V, Bridgman H, Kornhaber R, Cross M. The evidence for "flipping out": a systematic review of the flipped classroom in nursing education. Nurse Educ Today 2016;38:15-21.

12. Evans L, Vanden Bosch ML, Harrington S, Schoofs N, Coviak C. Flipping the classroom in health care higher education: a systematic review. Nurse Educ 2019;44:74-78.

13. El-Banna MM, Whitlow M, McNelis AM. Flipping around the classroom: accelerated Bachelor of Science in Nursing students' satisfaction and achievement. Nurse Educ Today 2017;56:41-46.

14. Hailikari T, Katajavuori N, Lindblom-Ylanne $S$. The relevance of prior knowledge in learning and instructional design. Am J Pharm Educ 2008;72:113.

15. Gillette C, Rudolph M, Kimble C, Rockich-Winston N, Smith L, Broedel-Zaugg K. A meta-analysis of outcomes comparing flipped classroom and lecture. Am J Pharm Educ 2018;82:6898.

16. Chen F, Lui AM, Martinelli SM. In response to Vanneman et al: "studies on the effectiveness of flipped classrooms." Med Educ 2018;52:877.

17. Martinelli SM, Chen F, Mcevoy MD, Zvara DA, Schell RM. Utilization of the flipped classroom in anesthesiology graduate medical education: an initial survey of faculty beliefs and practices about active learning. J Educ Periop Med 2018;20:E617.

18. Park KH, Park KH, Chae SJ. Experiences of medical teachers in flipped learning for medical students: a phenomenological study. Korean J Med Educ 2018;30:91-100.

19. Heitz C, Prusakowski M, Willis G, Franck C. Does the concept of the "flipped classroom" extend to the emergency medicine clinical clerkship? West J Emerg Med 2015;16:851-855.

20. Belfi LM, Bartolotta RJ, Giambrone AE, Davi C, Min RJ. Flipping the introductory clerkship in radiology: impact on medical student performance and perceptions. Acad Radiol 2015;22:794-801.

21. Schaefer SM, Dominguez M, Moeller JJ. The future of the lecture in neurology education. Semin Neurol 2018;38:418-427.

22. Galway LP, Corbett KK, Takaro TK, Tairyan K, Frank E. A novel integration of online and flipped classroom instruction models in public health higher education. BMC Med Educ 2014;14:181.

23. Boet S, Sharma S, Goldman J, Reeves S. Review article: medical education research: an overview of methods. Can J Anaesth 2012;59:159-170.

24. Fajardo LL, Chan KM. Evaluation of medical students in radiology: written testing using uncued multiple-choice questions. Invest Radiol 1993;28:964-968.

25. Sharma N, Lau CS, Doherty I, Harbutt D. How we flipped the medical classroom. Med Teach 2015;37:327-330.

Data available from SDC (references e1-e19): links.lww.com/WNL/A922 


\section{Neurology}

\section{Education Research: Flipped classroom in neurology: Principles, practices, and perspectives}

Stefano Sandrone, Jimmy V. Berthaud, Chad Carlson, et al. Neurology 2019;93;e106-e111

DOI 10.1212/WNL.0000000000007730

\section{This information is current as of July 1, 2019}

\section{Updated Information \& Services}

References

Subspecialty Collections

Permissions \& Licensing

Reprints including high resolution figures, can be found at: http://n.neurology.org/content/93/1/e106.full

This article cites 25 articles, 1 of which you can access for free at: http://n.neurology.org/content/93/1/e106.full\#ref-list-1

This article, along with others on similar topics, appears in the following collection(s):

All Education

http://n.neurology.org/cgi/collection/all_education Methods of education

http://n.neurology.org/cgi/collection/methods_of_education Other Education

http://n.neurology.org/cgi/collection/other_education

Information about reproducing this article in parts (figures,tables) or in its entirety can be found online at:

http://www.neurology.org/about/about_the_journal\#permissions

Information about ordering reprints can be found online:

http://n.neurology.org/subscribers/advertise

Neurology ${ }^{\circledR}$ is the official journal of the American Academy of Neurology. Published continuously since 1951, it is now a weekly with 48 issues per year. Copyright () 2019 American Academy of Neurology. All rights reserved. Print ISSN: 0028-3878. Online ISSN: 1526-632X.

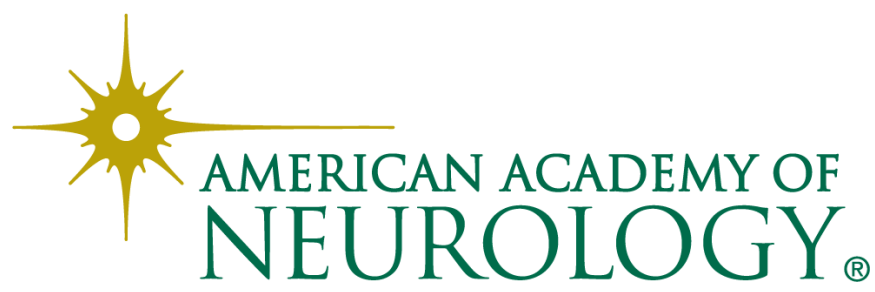

